\title{
Alternative Treatment Options in Patients with Colorectal Cancer Who Encounter Fluoropyrimidine-Induced Cardiotoxicity
}

This article was published in the following Dove Press journal: OncoTargets and Therapy

\section{Muhammad Wasif Saif (D) \\ NorthwellHealth Cancer Institute, Donald and Barbara Zucker School of Medicine at Hofstra, Feinstein Institute for Medical Research, Lake Success, New York, NY, USA}

\begin{abstract}
Fluorouracil (5-FU) remains to be the backbone of chemotherapy regimens approved for treatment of colorectal cancer and other gastrointestinal cancers and breast cancer. The incidence of cardiotoxicity associated with 5-FU ranges from 1.5-18\%. Previous studies also concluded that rechallenging a patient with previous 5-FU cardiotoxicity with either lower dose or another mode of administration could result in repeat of cardiac complication in up to $45 \%$ of patients. Nearly $13 \%$ of patients died upon re-exposure to 5-FU. Clinical manifestations of cardiac complications of fluoropyrimidines including angina, myocardial infarction, arrhythmias, hypotension, Tako-Tsubo syndrome, heart failure, cardiogenic shock, pericarditis, and even sudden death have been reported. Cardiotoxicity is unpredictable and no alternative chemotherapeutics have been defined so far. The author describes here treatment options for patients with metastatic colorectal cancer who have encountered fluoropyrimidine-induced cardiotoxicity, including switching to a different fluoropyrimidine, switching to a different schedule of intravenous 5-FU, or switching to a non-fluoropyrimidine-containing chemotherapy regimen if one exists. Switching to a non-fluoropyrimidine-containing chemotherapy regimen is usually the most feasible choice for patients with metastatic disease as data on adjuvant setting is usually a fluoropyrimidine or its combination with oxaliplatin at present.
\end{abstract}

Keywords: 5-FU, cardiotoxicity, fluoropyrimidines, 5-fluorouracil, DPD, dihydropyrimidine dehydrogenase, FBAL, fluoro-beta-alanine, TAS-102, uridine triacetate, S-1, capecitabine, UFT

\section{Introduction}

Fluoropyrimidines remain to be the backbone of regimens to treat many common solid tumors, including head and neck $(\mathrm{H} \& \mathrm{~N})$, breast, pancreas, stomach, anus, skin, small bowel, and especially colorectal cancer. ${ }^{1}$ As we continue to use these agents commonly, recognition of its related uncommon or under-recognized toxicities such as cardiac toxicity has also improved. Cardiotoxicity associated with either 5-FU or capecitabine is of utmost significance for many reasons. 5-FU is usually given orally or intravenously as a bolus or by continuous intravenous infusion and as a topical application. Intravenous $5-\mathrm{FU}$ is administered to nearly 275,000 cancer patients per year and capecitabine is taken by an additional 30,000 patients per year in the US. Moreover, 5-FU is usually administered for a series of cycles up to 6 months in adjuvant setting and till progression in advanced stages. Additionally, 5-FU administration continues in the second-line after progression in combination with other agents,
Correspondence: Muhammad Wasif Saif NorthwellHealth Cancer Institute, Donald and Barbara Zucker School of Medicine at Hofstra, Feinstein Institute for Medical Research, Lake Success, New York, NY I 1042, USA

Tel + I 5|6-32|-2238

Fax + $516-32 \mid-2272$

Email wsaif@northwell.edu 
eg FOLFOX to FOLFIRI. These statistics further underline the importance of recognizing and managing the cardiac toxicity associated with 5-FU and its analogs.

Clinical manifestations of cardiac complications of fluoropyrimidines may include angina, myocardial infarction, arrhythmias, hypotension, Tako-Tsubo syndrome, heart failure, cardiogenic shock, pericarditis, and even sudden death, ${ }^{2,4}$ as summarized in Table 1.

The underlying pathophysiological mechanisms to explain5-FU-induced cardiotoxicity remain undefined, but its association with mode and schedule of administration and genuine reproducibility have been wellrecognized. ${ }^{2,3}$ It is proposed to be multifactorial, and many mechanisms proposed include coronary spasm, direct myocardial ischemia due to endothelial damage, changes in platelet agreeability, abnormalities of coagulation proteins, an autoimmune reaction, result of pharmacogenetics related to 5-FU, such as dihydropyrimidine dehydrogenase (DPD) enzyme abnormality, direct effect of the catabolite, especially fluoro-beta-analine (FBAL) on the myocardium, or cardiotoxic impurities in 5-FU formulation $^{2,5}$ (Table 2 and Figure 1).

Several studies have also attempted to identify factors that might alter the incidence or severity of 5-FU-induced cardiac toxicity, including age, prior history of coronary artery disease, presence of comorbidities (smoking, hypertension, diabetes), and concomitant administration of other chemotherapeutic agents or radiation therapy. ${ }^{2-4,7}$ However, the majority of the cases reported previously had no such risk factors identified except few proposing an increased risk with concomitant administration of certain chemotherapeutics, such as 5-FU when used with cisplatin, or prior chest radiation, or combination of capecitabine with oxaliplatin and bevacizumab. ${ }^{2-8}$ We presented a met-analysis in 2001 which revealed that cardiac toxicity

Table I The Most Frequent Cardiac Complications Related to 5-FU Administration ${ }^{2}$

\begin{tabular}{|l|l|}
\hline \multicolumn{2}{|l|}{ Cardiac Manifestations of 5-FU/Capecitabine Toxicities } \\
\hline Cardiac Event & $\%$ \\
Angina & $45 \%$ \\
Myocardial infarction & $22 \%$ \\
Arrhythmias & $23 \%$ \\
(notably atrial fibrillation, VT, and VF) & \\
Acute pulmonary edema & $5 \%$ \\
Cardiac arrest & $1.4 \%$ \\
Pericarditis & $1.4 \%$ \\
Congestive heart failure & $2 \%$ \\
\hline
\end{tabular}

was associated with the longer duration of 5-FU administration and later we found similar toxicities associated with capecitabine, that mimics medium duration of the infusion. No relationship to dose was found. ${ }^{2,4}$ Reports include both chemo-naïve patients as well as those rechallenged after developing cardiac toxicity to 5 -FU. ${ }^{9}$

Previous studies have alarmed that rechallenging a patient with previous 5-FU cardiotoxicity with either a lower dose or another mode of administration could result in repeat of cardiac complication in up to $45 \%$ of patients. ${ }^{2,-7-9}$ Additionally, approximately $13 \%$ of patients died upon being re-exposed to 5-FU. ${ }^{2}$ Investigators have also evaluated the use of antianginal drugs with 5-FU and capecitabine. Two older studies looked at nitroglycerine and nifedipine and diltiazem. In one study, seven out of 300 patients manifested cardiac toxicity after administration of 5-FU with prophylactic nitroglycerin which failed to prevent EKG changes suggestive of myocardial ischemia during repeat infusion. ${ }^{10} \mathrm{~A}$ similar lack of protective efficacy was seen with either nifedipine $60 \mathrm{mg}$ /day, or diltiazem $80 \mathrm{mg}$ /day administered with simultaneous intravenous nitroglycerin at therapeutic doses. ${ }^{11}$ Eskilsson and Albertsson treated 58 patients receiving fluorouracil infusions with verapamil $120 \mathrm{mg}$ three times a day. They found evidence of ischemia in $12 \%$ of patients, compared with $13 \%$ in a previously studied comparable group not receiving prophylaxis. ${ }^{12}$ They concluded that calcium-channel blockade does not protect against cardiotoxicity. These data underline the fact that a rechallenge with 5-FU is not without risk and should be reserved only for those patients in whom there is no reasonable alternative therapy while observing aggressive prophylaxis and close monitoring.

The previous experience in investigating the cardiac toxicities of fluoropyrimidines, contribution to the clinical trials associated with development of S-1, TAS-102, and research in 5-FU pharmacogenetics of our group maintains my interest in managing 5-FU associated cardiotoxicity. ${ }^{8-10}$ The treatment options for patients who have encountered fluoropyrimidine-induced cardiotoxicity in patients with $\mathrm{CRC}$ can be broadly divided into three groups:

1. Switch to a different fluoropyrimidine,

2. Switch to a different schedule of intravenous 5-FU, or

3. Switch to a non-fluoropyrimidine-containing chemotherapy regimen if one exists.

Switching to a non-fluoropyrimidine-containing chemotherapy regimen is usually the most feasible choice 
Table 2 Potential Mechanisms Underlying 5-FU Cardiotoxicity ${ }^{2,5}$

\begin{tabular}{|c|c|}
\hline Mechanism & Results \\
\hline Autoimmune & $\begin{array}{l}\text { - A delayed immune reaction has been proposed } \\
\text { to explain 5-FU cardiotoxicity.These investiga- } \\
\text { tors also reported a beneficial effect of ster- } \\
\text { oids, further supporting the above possible } \\
\text { explanation. }\end{array}$ \\
\hline $\begin{array}{l}\text { Direct myocardial } \\
\text { damage }\end{array}$ & $\begin{array}{l}\text { - Edema of myocardial fibers and loss of stria- } \\
\text { tions were found within } 12 \text { hours of exposure } \\
\text { to } 5 \text {-FU in a rat model. } \\
\text { - Injected radiolabeled }{ }^{14} \text { C-labeled-5-FU into } \\
\text { a mouse model showed localization within the } \\
\text { myocardium which was retained for } 96 \text { hours } \\
\text { (longer than most organ systems).In another } \\
\text { preclinical study, repeated infusions of 5-FU } \\
\text { induced left ventricular hypertrophy, foci of } \\
\text { myocardial necrosis, thickening of intra- } \\
\text { myocardial arterioles, and disseminated apop- } \\
\text { tosis in myocardial cells of the epicardium, as } \\
\text { well as endothelial cells of the distal coronary } \\
\text { arteries. }\end{array}$ \\
\hline $\begin{array}{l}\text { Impurities in 5-FU } \\
\text { formulation }\end{array}$ & $\begin{array}{l}\text { - Commercial vials of 5-FU over time develop } \\
\text { 5-FU degradation products, ie, fluoroacetalde- } \\
\text { hyde (FACET) and fluoromalon-aldehydic acid } \\
\text { (Fmald) which are cardiotoxic in animal models. } \\
\text { Also, 5-FU gets metabolized into two com- } \\
\text { pounds, alpha-fluoro-beta-hydroxypropionic } \\
\text { acid (FHPA) and fluoroacetate, which are again } \\
\text { cardiotoxic. }\end{array}$ \\
\hline $\begin{array}{l}\text { Interference with } \\
\text { TCA cycle }\end{array}$ & $\begin{array}{l}\text { - Analysis of TCA cycle intermediates in animal } \\
\text { studies revealed an accumulation of citrate } \\
\text { within the myocardium, possibly resulting from } \\
\text { an inhibition of aconitase by fluorocitrate, as } \\
\text { a cause of depletion of the high-energy } \\
\text { phosphates.5-FU depletes high-energy phos- } \\
\text { phate compounds in the myocardium resulting } \\
\text { in metabolic dysfunction. }\end{array}$ \\
\hline Vasospasm & $\begin{array}{l}\text { - Administration of 5-FU caused vasospasm of } \\
\text { the aortic rings of rabbits which was dose } \\
\text { dependent. } \\
\text { - 5-FU may have a direct endothelial-independent } \\
\text { vasoconstriction secondary to activation of } \\
\text { PKC, probably via activation of PKC receptors. } \\
\text { An elevated level of endothelin-I (ET-I), } \\
\text { a potent natural vasoconstrictor, was found in } \\
\text { two patients with cardiac toxicity from 5-FU. }\end{array}$ \\
\hline Hypercoagulability & $\begin{array}{l}\text { Increase in fibrinopeptide A (FPA) levels and } \\
\text { decrease in Protein C activity as compared to } \\
\text { Protein C antigen levels was observed in a study } \\
\text { during the continuous infusion of 5-FU, which } \\
\text { returned to the baseline at the end of } 5 \text { days of } \\
\text { CIV. }\end{array}$ \\
\hline
\end{tabular}

(Continued)
Table 2 (Continued).

\begin{tabular}{|l|l|}
\hline Mechanism & Results \\
\hline Increased iron & $\begin{array}{l}\text { Increased iron content might be associated } \\
\text { with increased oxygen consumption.Animal } \\
\text { studies showed iron was 20\% higher compared } \\
\text { to time zero when measured by a Flame } \\
\text { Atomic absorption spectrophotometer, hence } \\
\text { supporting the cardiac ischemia related to } \\
\text { 5-FU. }\end{array}$ \\
\hline Cytotoxic effect & $\begin{array}{l}\text { The inhibition of mature cytoplasmic rRNA } \\
\text { production may be an important common } \\
\text { mechanism of RNA-directed cytotoxicity for all } \\
\text { the fluoropyrimidines }\end{array}$ \\
\hline $\begin{array}{l}\text { Effect on } \\
\text { erythrocytes }\end{array}$ & $\begin{array}{l}\text { Exposure of the erythrocytes to 5-FU irrever- } \\
\text { sibly affects their energetic metabolism as well } \\
\text { as their functioning. } \\
\text { Using } 3 \text { IIP NMR spectroscopy, a rapid increase } \\
\text { in O } 2 \text { consumption in 5-FU treated erythro- } \\
\text { cytes was observed which lead to severe } \\
\text { changes in the metabolism of phosphate com- } \\
\text { pounds in erythrocytes.Erythrocytes produced } \\
\text { more 2.3-BPG in order to maintain the meta- } \\
\text { bolism of oxygen within the physiological range, } \\
\text { which led to deoxygenation of oxy-Hb. This } \\
\text { made oxygen transport and/or delivery more } \\
\text { difficult, resulting in ischemic damage. }\end{array}$ \\
\hline
\end{tabular}

for patients with metastatic disease because data on adjuvant setting supports only the use usually of a fluoropyrimidine monotherapy, such as 5-FU or capecitabine or its combination with oxaliplatin at present. Table 3 summarizes other agents, including novel fluoropyrimidines and non-fluoropyrimidines, as alternative treatment options with cancer.

\section{Switch to a Different Fluoropyrimidines}

Table 3 summarizes the novel and other analogs of different fluoropyrimidines which may be considered as an alternative treatment for colorectal cancer patients who encountered cardiotoxicity to 5-FU or capecitabine. The composition, data on cardiac toxicity, potential mechanism of action responsible for lower incidence of cardiac toxicities, any comparison to 5-FU/capecitabine if available, and availability are summarized below.

\section{Switch to a Different Schedule of Intravenous 5-FU}

Previous data indicated that the incidence of 5-FU related cardiotoxicity is lower with a bolus schedule than with 


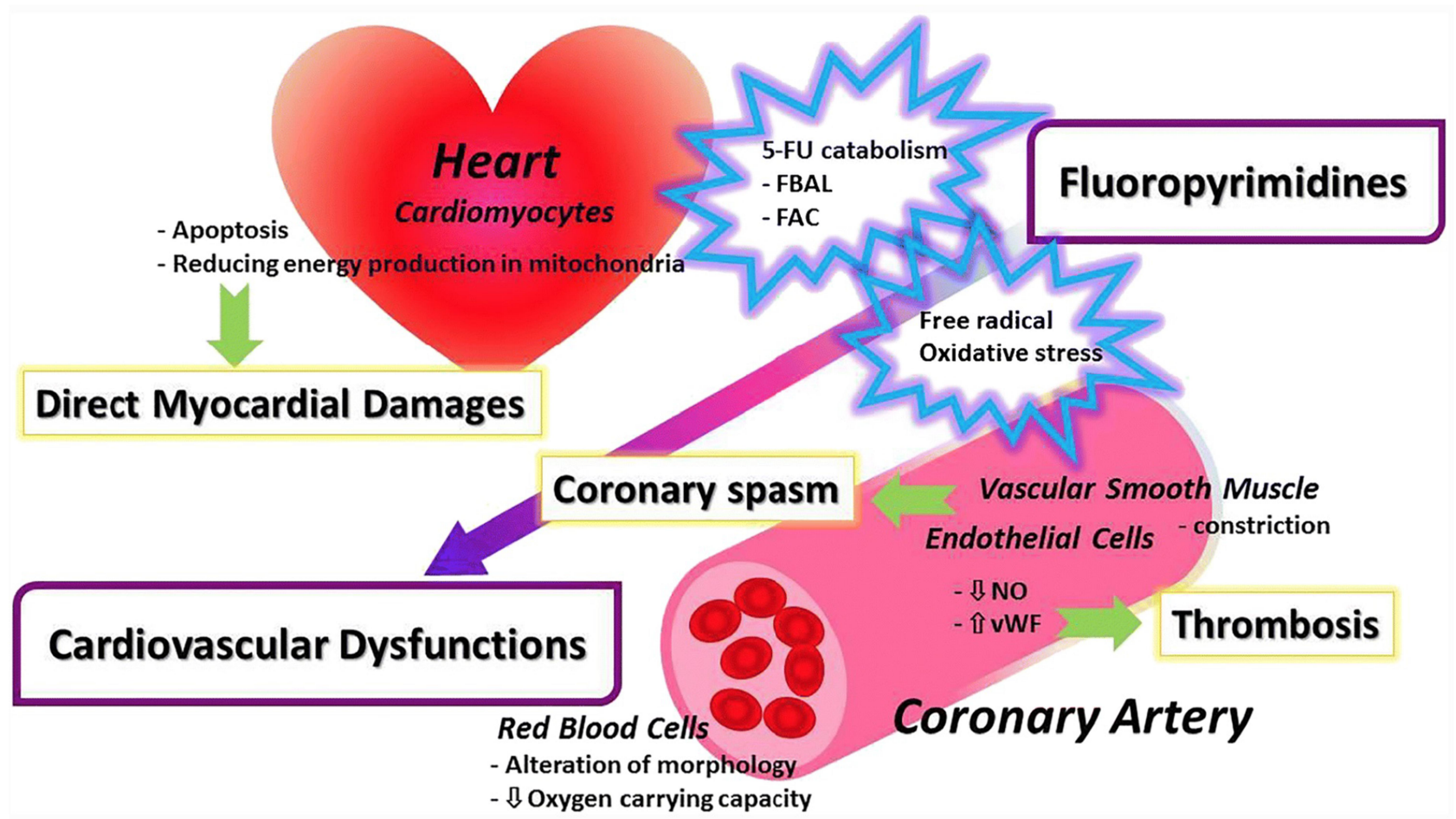

Mechanisms of direct cardiovascular toxicities and coronary spasm by FP. FBAL $\alpha$-fluoro- $\beta$-alanine, FAC fluoroacetate, NO nitric oxide, vWF von Willebrand factor

Figure I Mechanisms of cardiac toxicities associated with 5-FU/capecitabine Adapted from Shiga, T, Hiraide, M Cardiotoxicities of 5-Fluorouracil and Other Fluoropyrimidines. Curr. Treat. Options in Oncol. 2020;21(27). This article is licensed under a Creative Commons Attribution 4.0 International License, http://creative commons.org/licenses/by/4.0/. ${ }^{6}$

a continuous infusion schedule or oral capecitabine. Based on these observations, we further investigated the feasibility and safety that bolus 5-FU can be an alternative for patients who have developed cardiotoxicity while receiving 5-FU or capecitabine. To date, we have treated up to 13 patients safely with bolus 5 -FU. Table 4 summarizes the published cases of successful rechallenge with bolus 5-FU in patients who developed cardiotoxicity with infusional or oral fluoropyrimidine. ${ }^{24,25}$

Interestingly, capecitabine was rechallenged in few of these patients in our experience but sadly all of them developed similar symptoms, leading to cessation of the drug. It is of utmost importance to understand that the experience with this strategy is limited to only a few cases and that bolus 5-FU has also been associated with cardiac toxicity as well. We believe that 5-FU is rapidly cleared from the blood stream following bolus 5-FU (half-life of 15-20 minutes) and probably a direct effect of drug on cardiac systems is unlikely, as seen in these cases. ${ }^{24,25}$ However, at present we do not endorse use of bolus 5 -FU unless done in a vigorous environment in consultation with the cardiology team and discontinue 5-FU immediately if a cardiac event occurs. It is also important to remember that a delayed onset cardiotoxicity has also been reported in the literature and demands a close followup.

\section{Switch to a Non-Fluoropyrimidine Containing Chemotherapy Regimen}

Switching to a non-fluoropyrimidine-containing chemotherapy regimen is the most viable option for patients with mCRC. Table 5 summarizes the data on these regimens.

\section{Summary}

To sum up, 5-FU cardiotoxicity is an infrequent, but a real phenomenon. It is probable that 5-FU cardiotoxicity may be much more common and clinically significant than previously reported as awareness has risen due to continued use, many 5-FU based regimens, longer duration on therapy, and availability of novel agents. ${ }^{2,42,43}$ Although the history of pre-existing coronary artery disease may increase the risk of cardiac toxicity associated with 5-FU/capecitabine, the published data does not seem to 
Table 3 Switch to a Different Fluoropyrimidine

\begin{tabular}{|c|c|c|c|c|c|}
\hline Drug & Composition & Cardiac Safety & $\begin{array}{l}\text { Mechanism of Potential } \\
\text { Decreased Cardiac Toxicity }\end{array}$ & $\begin{array}{l}\text { Comparison or } \\
\text { Challenge After 5-FU } \\
\text { and Capecitabine }\end{array}$ & Availability \\
\hline $\begin{array}{l}\text { TAS-102 } \\
\text { (Lonsurf) }\end{array}$ & $\begin{array}{l}\text { TAS- } 102 \text { consists of } \\
\text { nucleoside analog } \\
\text { (trifluridine) and } \\
\text { a thymidine } \\
\text { phosphorylase inhibitor } \\
\text { (tipiracil). }{ }^{13}\end{array}$ & $\begin{array}{l}\text { We performed a meta- } \\
\text { analysis of } 869 \\
\text { publications including } \\
\text { I877 patients. Compared } \\
\text { with placebo, TAS- } 102 \text { did } \\
\text { not increase the risk of } \\
\text { myocardial infarction } \\
(\mathrm{OR}=1.97 ; 95 \% \\
\mathrm{Cl}=0.22-17.89) \text {, } \\
\text { hypertension }(\mathrm{OR}=0.73 \text {; } \\
95 \% \mathrm{Cl}=0.37-1.44) \text {, } \\
\text { palpitations }(\mathrm{OR}=1.51 \text {; } \\
95 \% \mathrm{Cl}=0.30-7.56) \\
\text { cardio-pulmonary arrest } \\
(\mathrm{OR}=0.83 ; 95 \% \\
\mathrm{Cl}=0.1 \mathrm{I}-6.32) \text {, or } \\
\text { syncope }(\mathrm{OR}=1.50 ; 95 \% \\
\mathrm{Cl}=0.06-37.14){ }^{14}\end{array}$ & $\begin{array}{l}\text { I.TAS I02 has a different } \\
\text { oncological target (tri- } \\
\text { fluorothymidine monophosphate } \\
\text { [TF-TMP] and tri-fluorothymidine } \\
\text { triphosphate [TF-TTP]) vs 5-FU } \\
\text { or capecitabine (FdUMP } \\
\text { fluorodeoxyuridine } \\
\text { monophosphate [FdUMP] and } \\
\text { fluorodeoxyuridine triphosphate } \\
\text { [FdUTP]). } \\
\text { 2.Possibly higher tumoral } \\
\text { incorporation of FTD into DNA } \\
\text { than its incorporation into normal } \\
\text { tissues DNA, thereby, decreasing } \\
\text { cardiac damage. } \\
\text { 3.Finally, TAS I02 is not } \\
\text { catabolized by DPD, hence } \\
\text { cardiotoxic catabolites of 5-FU, } \\
\text { such as FBAL, F-citrate are } \\
\text { significantly lower quantitatively } \\
\text { resulting in less cardiotoxicity. }\end{array}$ & $\begin{array}{l}\text { In the registration Phase } \\
\text { III study that led to its } \\
\text { FDA approval, only one } \\
\text { patient treated with TAS- } \\
102 \text { was reported to have } \\
\text { an episode of cardiac } \\
\text { ischemia among } 800 \\
\text { treated patients who have } \\
\text { been exposed to 5-FU } \\
\text { previously. }\end{array}$ & $\begin{array}{l}\text { Approved only for } \\
\text { refractory colon and } \\
\text { gastric cancer at present } \\
\text { in the US. }\end{array}$ \\
\hline S-I & $\begin{array}{l}\text { S-I contains tegafur (FF) } \\
\text { and two types of enzyme } \\
\text { inhibitor, gimeracil/ } \\
\text { 5-chloro- } \\
\text { 2,4-dihydroxypyridine } \\
\text { (CDHP) a potent } \\
\text { inhibitor of DPD and } \\
\text { potassium oxonate (Oxo) } \\
\text { which inhibits } \\
\text { phosphorylation of } \\
\text { intestinal 5-FU in a molar } \\
\text { ratio of I:0.4: I. }{ }^{16}\end{array}$ & $\begin{array}{l}\text { In the published Phase II } \\
\text { or III studies of S-I, no } \\
\text { grade III or IV } \\
\text { cardiovascular events } \\
\text { were reported. }{ }^{16}\end{array}$ & $\begin{array}{l}\text { I.S-I is an oral DPD inhibitory } \\
\text { fluoropyrimidine (DIF) based on } \\
\text { a biochemical modulation of 5-FU. } \\
\text { Gimeracil is a highly active } \\
\text { reversible DPD inhibitor, I80-fold } \\
\text { more active than uracil (the DPD } \\
\text { inhibitor in UFT). Because of the } \\
\text { significant DPD inhibition by } \\
\text { gimeracil, levels of cardiotoxic } \\
\text { catabolites of 5-FU levels are } \\
\text { significantly lower than after } \\
\text { capecitabine or I.V. 5-FU } \\
\text { administration, and hence less } \\
\text { cardiotoxicity can be expected. }{ }^{17}\end{array}$ & $\begin{array}{l}\text { Experience with S-I in } \\
\text { CRC patients with } \\
\text { previous 5-FU- or } \\
\text { capecitabine-induced } \\
\text { cardiotoxicity is limited to } \\
\text { anecdotal reports. }{ }^{18}\end{array}$ & $\begin{array}{l}\text { S-I is approved in Japan, } \\
\text { China, Taiwan, Korea, } \\
\text { Singapore, and European } \\
\text { countries but not } \\
\text { available in the US. }\end{array}$ \\
\hline UFT & $\begin{array}{l}\text { Combination of ftorafur } \\
\text { with uracil, which UFT. } \\
\text { Uracil competitively } \\
\text { inhibits the enzyme DPD, } \\
\text { leading to higher } \\
\text { intratumoral } \\
\text { concentrations of 5-FU.19 }\end{array}$ & $\begin{array}{l}\text { In animal experiments, } \\
\text { adding uracil to tegafur } \\
\text { reduced cardiotoxicity as } \\
\text { compared with tegafur } \\
\text { alone. }^{15} \\
\text { Cardiotoxicity, such as } \\
\text { angina pectoris, }^{\text {arrhythmia, congestive }} \\
\text { heart failure, myocardial } \\
\text { infarction, and cardiac } \\
\text { arrest have been reported } \\
\text { in only I\% with UFT than } \\
\text { with 5-FU or } \\
\text { capecitabine. }\end{array}$ & $\begin{array}{l}\text { Uracil is a natural substrate for } \\
\text { DPD, and competes with 5-FU for } \\
\text { this enzyme, reducing the } \\
\text { degradation of } 5 \text {-FU to its toxic } \\
\text { metabolites FBAL and F-citrate. }\end{array}$ & $\begin{array}{l}\text { The experience with this } \\
\text { strategy is limited to } \\
\text { isolated case reports. } \\
\text { However, report of death } \\
\text { of one patient following } \\
\text { rechallenge with UFT who } \\
\text { had prior cardiotoxicity } \\
\text { associated with I.V. 5-FU } \\
\text { (De Gramont's schedule) } \\
\text { has been published. }\end{array}$ & $\begin{array}{l}\text { UFT has been in } \\
\text { widespread use in many } \\
\text { areas worldwide, } \\
\text { including Japan, Asia, } \\
\text { South America, and } \\
\text { Spainfor over } 20 \text { years. } \\
\text { UFT is not available in the } \\
\text { US. }\end{array}$ \\
\hline
\end{tabular}

(Continued) 
Table 3 (Continued).

\begin{tabular}{|c|c|c|c|c|c|}
\hline Drug & Composition & Cardiac Safety & $\begin{array}{l}\text { Mechanism of Potential } \\
\text { Decreased Cardiac Toxicity }\end{array}$ & $\begin{array}{l}\text { Comparison or } \\
\text { Challenge After 5-FU } \\
\text { and Capecitabine }\end{array}$ & Availability \\
\hline Raltitrexed & $\begin{array}{l}\text { Raltitrexed is chemically } \\
\text { similar to folic acid and is } \\
\text { in the class of } \\
\text { chemotherapy drugs } \\
\text { called folate } \\
\text { antimetabolites, which } \\
\text { inhibit one or more of } \\
\text { three enzymes that use } \\
\text { folate and derivatives as } \\
\text { substrates: DHFR, } \\
\text { GARFT and thymidylate } \\
\text { synthase. } \\
\text { Raltitrexed is fully active } \\
\text { after polyglutamylation, } \\
\text { which allows cellular } \\
\text { retention of the drug. } \\
\text { By inhibiting Thymidylate } \\
\text { synthase (TS), thus } \\
\text { formation of precursor } \\
\text { pyrimidine nucleotides, } \\
\text { raltitrexed prevents the } \\
\text { formation of DNA and } \\
\text { RNA, which are required } \\
\text { for the growth and } \\
\text { survival of both normal } \\
\text { cells and cancer cells. }{ }^{21}\end{array}$ & $\begin{array}{l}\text { Raltitrexed alone as well } \\
\text { as in combination with } \\
\text { oxaliplatin or irinotecan } \\
\text { provides a safe option in } \\
\text { terms of cardiac toxicity } \\
\text { for such patients based on } \\
\text { previous studies. }\end{array}$ & $\begin{array}{l}\text { The metabolism of raltitrexed is } \\
\text { independent of DPD. Other than } \\
\text { its intracellular polyglutamation, } \\
\text { raltitrexed is not metabolized and } \\
\text { is excreted largely unchanged in } \\
\text { the urine. }\end{array}$ & $\begin{array}{l}\text { Ransom et al have } \\
\text { published a successful } \\
\text { rechallenge with } \\
\text { raltitrexed in } 42 \text { patients } \\
\text { with } \mathrm{mCRC} \text { who had to } \\
\text { stop 5-FU or capecitabine } \\
\text { due to cardiotoxicity. No } \\
\text { patient suffered any } \\
\text { subsequent cardiac } \\
\text { problems. }\end{array}$ & $\begin{array}{l}\text { Overall, raltitrexed is } \\
\text { considered inferior to } \\
5 \text {-FU because of higher } \\
\text { treatment-related } \\
\text { mortality and is therefore } \\
\text { not widely available. } \\
\text { Currently, available in } \\
\text { Canada, Europe, } \\
\text { Singapore, and Middle } \\
\text { East only. }\end{array}$ \\
\hline
\end{tabular}

Table 4 Summary of Few Cases Rechallenged with Bolus5-FU

\begin{tabular}{|c|c|c|c|c|c|}
\hline $\begin{array}{l}\text { Pt. } \\
\text { No }\end{array}$ & $\begin{array}{l}\text { Age, } \\
\text { Years }\end{array}$ & Sex & Regimen & $\begin{array}{l}\text { Re-Challenge } \\
\text { with Bolus 5-FU }\end{array}$ & Outcome \\
\hline 1 & 35 & M & FOLFOX & FLOX & $\begin{array}{l}\text { Tolerated without cardiac symptoms } \\
\text { and signs }\end{array}$ \\
\hline 2 & 34 & M & $\begin{array}{l}\text { 5-FU CIV with concurrent } \\
\text { XRT }\end{array}$ & $\begin{array}{l}\text { Bolus 5-FU with LCV on Mon/Wed/Fri per } \\
\text { week }\end{array}$ & $\begin{array}{l}\text { Tolerated without cardiac symptoms } \\
\text { and signs }\end{array}$ \\
\hline 3 & 54 & $M$ & FOLFOX & FLOX & $\begin{array}{l}\text { Tolerated without cardiac symptoms } \\
\text { and signs }\end{array}$ \\
\hline 4 & 39 & $M$ & $\begin{array}{l}\text { 5-FU CIV with concurrent } \\
\text { XRT }\end{array}$ & $\begin{array}{l}\text { Bolus 5-FU with LCV on Mon/Wed/Fri per } \\
\text { week }\end{array}$ & $\begin{array}{l}\text { Tolerated without cardiac symptoms } \\
\text { and signs }\end{array}$ \\
\hline 5 & 56 & M & $\begin{array}{l}\text { 5-FU CIV with concurrent } \\
\text { XRT }\end{array}$ & $\begin{array}{l}\text { Bolus 5-FU with LCV on Mon/Wed/Fri per } \\
\text { week }\end{array}$ & $\begin{array}{l}\text { Tolerated without cardiac symptoms } \\
\text { and signs }\end{array}$ \\
\hline 6 & 61 & M & ECF & Weekly bolus 5-FU and LCV & $\begin{array}{l}\text { Tolerated without cardiac symptoms } \\
\text { and signs }\end{array}$ \\
\hline
\end{tabular}

Abbreviations: FOLFOX: oxaliplatin, 5-FU and leucovorin; ECF: Epirubicin, cisplatin and 5-FU, NA: not available; LCV: leucovorin, CIV: continuous infusion of 5-FU, XRT: radiotherapy 
Table 5 Non-Fluoropyrimidine Containing Chemotherapy Regimen

\begin{tabular}{|c|c|c|}
\hline Agent & Line of Therapy & Any Potential Cardiac Toxicity \\
\hline $\begin{array}{l}\text { Irinotecan as a single } \\
\text { agent }\end{array}$ & Second-line irinotecan alone for advanced $C R C^{26}$ & Not reported. \\
\hline $\begin{array}{l}\text { Irinotecan in } \\
\text { combination with } \\
\text { Cetuximab }\end{array}$ & $\begin{array}{l}\text { Cetuximab plus irinotecan with irinotecan alone after } \\
\text { fluoropyrimidine and oxaliplatin failure in } \mathrm{mCRC} \text { patients with } \\
\text { KRAS wild type. }{ }^{27}\end{array}$ & Not reported. \\
\hline $\begin{array}{l}\text { Irinotecan in } \\
\text { combination with } \\
\text { aflibercept (zaltrap) }\end{array}$ & $\begin{array}{l}\text { Velour study showed superiority of FOLFIRI plus aflibercept } \\
\text { compared to FOLFIRI in patients who have failed oxaliplatin-based } \\
\text { regimen with or without bevacizumab. }{ }^{28}\end{array}$ & $\begin{array}{l}\text { Like other anti-VEGF agents are known to cause arterial } \\
\text { thromboembolism. }\end{array}$ \\
\hline $\begin{array}{l}\text { Oxaliplatin as } \\
\text { a single agent }\end{array}$ & $\begin{array}{l}\text { Oxaliplatin as monotherapy was initially approved in the second- } \\
\text { line setting in Europe. }{ }^{29} \text { However, later studies showed inferiority } \\
\text { of oxaliplatin over its combination with } 5 \text {-FU. Monotherapy use of } \\
\text { oxaliplatin is generally not recommended, especially in the US, } \\
\text { based on ECOG E3200 study. }\end{array}$ & No known cardiotoxicity. \\
\hline $\begin{array}{l}\text { Combining } \\
\text { irinotecan with } \\
\text { oxaliplatin (IROX) }\end{array}$ & $\begin{array}{l}\text { IROX regimen has documented activity in phase III studies in first } \\
\text { and second-line treatment of metastatic CRC. }{ }^{30} \text { But it is important } \\
\text { to remember that the efficacy of IROX was significantly inferior to } \\
\text { FOLFOX in first-line treatment. } \\
\text { In second-line treatment after } 5 \text {-FU failure, IROX was found to be } \\
\text { superior to irinotecan monotherapy. }{ }^{31}\end{array}$ & Not reported. \\
\hline $\begin{array}{l}\text { Cetuximab or } \\
\text { panitumumab } \\
\text { monotherapy }\end{array}$ & $\begin{array}{l}\text { Cetuximab and panitumumab are active as a single agent in chemo- } \\
\text { refractory } \mathrm{mCRC} \text { patients with K-RAS wild type tumors. }{ }^{32,33}\end{array}$ & Not reported. \\
\hline Regorafenib & $\begin{array}{l}\text { Regorafenib has been approved to treat } \mathrm{mCRC} \text { that has } \\
\text { progressed after all standard therapies (fluoropyrimidine-, } \\
\text { oxaliplatin-, and irinotecan-based chemotherapy, an anti-VEGF } \\
\text { therapy, and, if KRAS wild type, an anti-EGFR therapy). }{ }^{34}\end{array}$ & $\begin{array}{l}\text { Like other anti-VEGF agents are known to cause arterial } \\
\text { thromboembolism. }\end{array}$ \\
\hline TAS- 102 & $\begin{array}{l}\text { TAS- } 102 \text { has been approved to treat mCRC that has progressed } \\
\text { after all standard therapies (fluoropyrimidine-, oxaliplatin-, and } \\
\text { irinotecan-based chemotherapy, an anti-VEGF therapy, and, if } \\
\text { KRAS wild type, an anti-EGFR therapy). }{ }^{15}\end{array}$ & $\begin{array}{l}\text { In the registration RECOURSE phase III study that led to its } \\
\text { FDA approval, only one patient treated with TAS- } 102 \text { was } \\
\text { reported to have an episode of cardiac ischemia among } 800 \\
\text { treated patients who have been exposed to 5-FU previously. }\end{array}$ \\
\hline $\begin{array}{l}\text { Immunotherapy (for } \\
\text { MSI-high) }\end{array}$ & $\begin{array}{l}\text { In May } 2017 \text {, the FDA granted approval for using pembrolizumab, } \\
\text { a programmed cell death protein I (PD-I) antibody, in patients } \\
\text { with microsatellite unstable mCRC. }{ }^{35}\end{array}$ & $\begin{array}{l}\text { Cases of cardiotoxicity, such as myocarditis, Tako-Tsubo } \\
\text { cardiomyopathy, cardiac arrest, myocardial infarction, have } \\
\text { been reported, that usually occur immediately after the } \\
\text { infusion or during the first year of therapy. }\end{array}$ \\
\hline Mitomycin (MMC) & $\begin{array}{l}\text { Data does not support use of single agent based on a multicenter, } \\
\text { multinational analysis of mitomycin C in refractory metastatic } \\
\text { colorectal cancer. } \\
\text { MIXE regimen (mitomycin plus capecitabine) has shown activity as } \\
\text { salvage therapy but cannot be recommended due to capecitabine's } \\
\text { cardiotoxicity previously discussed. }{ }^{37}\end{array}$ & $\begin{array}{l}\text { MMC has been implicated as a possible cardiotoxic agent } \\
\text { (CHF). }\end{array}$ \\
\hline $\begin{array}{l}\text { Mitomycin (MMC) + } \\
\text { Oxaliplatin (MOX) }\end{array}$ & $\begin{array}{l}\text { One possible alternative regimen is MOX (mitomycin with } \\
\text { oxaliplatin) which has shown some activity in salvage setting of } \\
\mathrm{mCRC}^{38} \\
\text { We recently published the first case series that reports the safety } \\
\text { and feasibility of s-MOX in patients with } \mathrm{mCRC} \text { who developed } \\
\text { cardiac toxicity to } 5 \text {-FU or capecitabine }{ }^{4,8,9,39}\end{array}$ & $\begin{array}{l}\text { Overall, the s-MOX regimen was well tolerated. } \\
\text { The most common toxicities included < grade } 2 \text { peripheral } \\
\text { neuropathy, nausea, vomiting, thrombocytopenia, and } \\
\text { anemia. }{ }^{38}\end{array}$ \\
\hline
\end{tabular}


Table 5 (Continued).

\begin{tabular}{|c|c|c|}
\hline Agent & Line of Therapy & Any Potential Cardiac Toxicity \\
\hline $\begin{array}{l}\text { Mitomycin (MMC) + } \\
\text { Irinotecan (MIRI) }\end{array}$ & $\begin{array}{l}\text { MIRI regimen (mitomycin with irinotecan) has also shown some } \\
\text { activity in salvage setting of } \mathrm{mCRC} .49,40 \\
\text { We have developed a modified regimen (s-MIRI - unpublished) } \\
\text { administering mitomycin } 7 \mathrm{mg} / \mathrm{m}^{2} \text { on day I and irinotecan I50 mg/ } \\
\mathrm{m}^{2} \text { on day I and day I5 every } 28 \text { days (unpublished) which was } \\
\text { found to be safer without any recurrent cardiac toxicities in five } \\
\text { patients who had previously encountered cardiotoxicity to 5-FU } \\
\text { and/or capecitabine (unpublished). }\end{array}$ & $\begin{array}{l}\text { s-MIRI did not result in recurrent cardiac toxicities in five } \\
\text { patients who had previously encountered cardiotoxicity to } \\
\text { 5-FU and/or capecitabine (unpublished). }\end{array}$ \\
\hline TAS- 102 & $\begin{array}{l}\text { TAS-102 shares similarities with fluoropyrimidines, but its } \\
\text { mechanism of action is distinct. In some investigators' opinion, } \\
\text { switching to TAS- } 102 \text { should be considered as switching to a non- } \\
\text { fluoropyrimidine. }{ }^{3,114}\end{array}$ & $\begin{array}{l}\text { There is ample data suggesting that TAS-102 is the first } \\
\text { "cardio-gentle" fluoropyrimidine in the colorectal cancer } \\
\text { landscape. }\end{array}$ \\
\hline
\end{tabular}

underline the predictive value of the presence of cardiac risk factors for the development of 5-FU-induced cardiac side-effects. Therefore, caution must be taken in treating these patients and if any signs or symptoms suggest cardiotoxicity, the drug should be suspended and a thorough work-up must be performed with multidisciplinary approach.

Despite a known benefit of nitrates and calcium channel blockers in ischemic heart disease, the effectiveness of this prophylactic therapy in patients receiving 5-FU/capecitabine has not been consistent. ${ }^{10-12}$ Few other reports indicated that beta-blockers should be avoided as they can be spasmogenic. Use of prophylactic use of anti-anginal agents has not been consistent. Cianci et al ${ }^{44}$ reported their experience with three cases of 5-FU-associated cardiotoxicity who received prophylactic transepidermal nitroglycerin. In this case series, they reported that the patients did not develop ischemic symptoms, such as angina. Kinhult et al ${ }^{45}$ showed that dalteparin, an antithrombotic, can protect against thrombogenic effects of 5-FU, secondary to its direct toxic effect on the vascular endothelium.

We recommend assessment of traditional cardiovascular risk factors and optimal management of cardiovascular disease, as a part of routine care for all patients before, during, and after receiving 5-FU/capecitabine (Table 6). However, in any patient who develops symptoms suggestive of ischemia, such as angina and/or electrocardiographic evidence of myocardial ischemia during the administration of 5-FU and capecitabine, termination of chemotherapy and administration of nitrates or calcium channel blockers should be considered under close observation. Cardiology consultation must be carried out and risk stratification should be performed. It is important to keep in mind that rechallenging these patients with similar agents can result in reoccurrence of cardiac toxicity. In addition to ischemic toxicity, arrhythmias also

Table 6 Suggested Recommendations

\begin{tabular}{|l|}
\hline Pre-treatment \\
\hline History: Cardiac disease, risk factors, cardiotoxic medications \\
Family History \\
Exam: Cardiac, weight \\
Tests: Baseline EKG \\
\hline During treatment \\
\hline Monitor for cardiovascular symptoms \\
Weight and Fluid balance \\
Electrolyte monitoring (especially when used in combination with \\
cisplatin) \\
Be careful when administering 5-FU with other cardiotoxic drugs, \\
including anti-VEGF agents \\
Immediately stop infusion or capecitabine if cardiovascular symptom \\
develops (including hypotension) \\
Treat with conventional therapy for such cardiac event \\
Complete cardiac work-up \\
\hline Re-challenge \\
\hline Only perform in selected patients if clinically important and no \\
alternate therapy available \\
Close monitoring \\
Consider continuous electrocardiographic monitoring \\
Consult a cardiologist \\
Otherwise consider alternative treatment options \\
\hline
\end{tabular}


occur in these patients. Therefore, ECG monitoring is recommended if there is any suspicion leading to cardiotoxicity of these agents. ${ }^{46}$ In addition to non-invasive diagnostic tests, coronary angiography should be considered in patients who develop ischemia during or following 5-FU/capecitabine. Cardiac toxicity with newer oral 5-FU agents seem to be of less frequency, especially TAS-102, which is more widely available compared to older agents, such as S- 01 or S-1 or UFT. In the adjuvant setting, only UFT and raltitrexed as a single agent have documented activity in randomized phase III trials, and experience with combination regimens is scarce. As mentioned earlier, re-challenge with 5-FU/capecitabine after an episode of cardiac toxicity to these agents can pose a higher risk of complications, including sudden cardiac death. ${ }^{2}$ Therefore, one must consider immediate termination of these chemotherapeutic drugs and modification of the treatment regimen.

It is worth-mentioning here that in 2015, uridine triacetate, an oral active prodrug of uridine, which is a naturally occurring nucleoside and competes with the 5-FU metabolite for incorporation into RNA of normal tissue, was approved by the Food and Drug Administration (FDA) as an antidote to 5 -FU (or capecitabine). ${ }^{47}$ In a study, 137 of 142 overdose patients who were treated with uridine triacetate had a rapid reversal of severe acute cardiotoxicity. ${ }^{47}$ The indications included use of uridine triacetate in patients with overdose or for those who exhibit early-onset, severe, or lifethreatening toxicity affecting the cardiac or central nervous system, and/or early onset, unusually severe adverse reactions (eg, gastrointestinal toxicity and/or neutropenia). It is worth mentioning here that overdose of 5-FU/capecitabine is not the most responsible for its cardiotoxicity. In fact, the majority is regarding to normal chemotherapy regimens and not overdose. At present, the use of this antidote to prevent or treat cardiac toxicity of 5-FU has not been studied and warrants future studies to clarify its role in the treatment of fluoropyrimidine associated cardiotoxicity.

\section{Funding}

Partly funded by R01 CA085381.

\section{Disclosure}

The author reports no conflicts of interest for this work.

\section{References}

1. Myers CE. The pharmacology of the fluoropyrimidines. Pharmacol Rev. 1981;33:1-15.
2. Saif MW, Shah MM, Shah AR. Fluoropyrimidine-associated cardiotoxicity: revisited. Expert Opin Drug Saf. 2009;8(2):191-202. doi:10.1517/14740330902733961

3. Anand AJ. Fluorouracil cardiotoxicity. Ann Phanrmacother. 1994;28 (3):374-378. doi:10.1177/106002809402800314

4. Saif MW, Tomita M, Ledbetter L, Diasio RB. Capecitabine-related cardiotoxicity: recognition and management. J Support Oncol. 2008;6(1):41-48.

5. Norwood RA, Lokich JJ, Moore C. The syndrome of 5-fluorouracil cardiotoxicity: an elusive cardiopathy. Cancer. 1993;72:2287-2288.

6. Shiga T, Hiraide M. Cardiotoxicities of 5-Fluorouracil and other fluoropyrimidines. Curr Treat Options in Oncol. 2020;21(27). doi:10.1007/s11864-020-0719-1

7. Jensen SA, Sorensen JB. Risk factors and prevention of cardiotoxicity induced by 5 -fluorouracil or capecitabine. Cancer Chemother Pharmacol. 2006;58:487-493. doi:10.1007/s00280-005-0178-1

8. Kwakman JJ, Simkens LH, Mol L, Kok WE, Koopman M, Punt CJ. Incidence of capecitabine-related cardiotoxicity in different treatment schedules of metastatic colorectal cancer: A retrospective analysis of the CAIRO studies of the Dutch colorectal cancer group. Eur J Cancer. 2017;76:93-99. doi:10.1016/j. ejca.2017.02.009

9. Van Cutsem E, Hoff PM, Blum JL, et al. Incidence of cardiotoxicity with the oral fluoropyrimidine capecitabine is typical of that reported with 5-fluorouracil. Ann Oncol. 2002;13:484-485. doi:10.1093/ annonc/mdf108

10. Akpek G, Hartshorn KL. Failure of oral nitrate and calcium channel blocker therapy to prevent 5-fluorouracil-related myocardial ischemia: a case report. Cancer Chemother Pharmacol. 1999;43 (2):157-161. doi:10.1007/s002800050877

11. Oleksowicz L, Bruckner HW. Prophylaxis of 5-fluorouracil-induced coronary vasospasm with calcium channel blockers. Am J Med. 1988;85:750-751. doi:10.1016/S0002-9343(88)80268-7

12. Eskilsson J, Albertsson M. Failure of preventing 5-fluorouracil cardiotoxicity by prophylactic treatment with verapamil. Acta Oncol. 1990;29(8):1001-1003. doi:10.3109/02841869009091790

13. Chen J, Han M, Saif MW. TAS-102 an Emerging Oral Fluoropyrimidine. Anticancer Res. 2016;36(1):21-26.

14. Lopez CA, Azimi-Nekoo E, Chung SY, Newman J, Shen J, Saif MW. Meta-analysis and systematic review of the cardiotoxicity of TAS- 102 . JCO. 2020;38:e16053e16053. doi:10.1200/JCO.2020.38.15_suppl. e16053

15. Mayer RJ, Van Cutsem E, Falcone A, et al. Randomized trial of TAS-102 for refractory metastatic colorectal cancer. $N$ Engl $J$ Med. 2015;372(20):1909-1919. doi:10.1056/NEJMoa1414325

16. Saif MW, Syrigos KN. Katirtzoglou NA. S-1: a promising new oral fluoropyrimidine derivative. Expert Opin Investig Drugs. 2009;18 (3):335-348. doi:10.1517/13543780902729412

17. Saif MW, Rosen LS, Saito K, Zergebel C, Ravage-Mass L, Mendelson DS. A Phase I study evaluating the effect of CDHP as a component of S-1 on the pharmacokinetics of 5-fluorouracil. Anticancer Res. 2011;31(2):625-632.

18. Franck C, Malfertheiner P, Venerito M. Safe administration of S-1 after 5-fluorouracil-induced cardiotoxicity in a patient with colorectal cancer. BMJ Case Rep. 2017;2017:bcr2016219162. doi:10.1136/bcr-2016219162

19. Yamamoto J, Haruno A, Yoshimura Y, et al. Effect of coadministration of uracil on the toxicity of tegafur. $J$ Pharm Sci. 1984;73:212-214. doi:10.1002/jps.2600730217

20. Kikuchi K, Majima S, Murakami M. Clinical survey on cardiotoxicity of tegafur (FT-207) compilation of a nationwide survey. Gan to Kagaku Ryoho. 1982;9((8):):1482-1488.

21. Köhne CH, Thuss-Patience P, Friedrich M, et al. Raltitrexed (Tomudex): an alternative drug for patients with colorectal cancer and 5-fluorouracil associated cardiotoxicity. Br J Cancer. 1998;77 (6):973-977. doi:10.1038/bjc.1998.160 
22. Van Cutsem E, Cunningham D, Maroun J, Cervantes A, Glimelius B. Raltitrexed: current clinical status and future directions. Ann Oncol. 2002;13(4):513-522. doi:10.1093/annonc/mdf054

23. Ransom D, Wilson K, Fournier M, et al. Final results of australasian gastrointestinal trials group ARCTIC study: an audit of raltitrexed for patients with cardiac toxicity induced by fluoropyrimidines. Ann Oncol. 2014;25:117-121. doi:10.1093/annonc/mdt479

24. Saif MW, Garcon MC, Rodriguez G, Rodriguez T. Bolus 5 -fluorouracil as an alternative in patients with cardiotoxicity associated with infusion 5- fluorouracil and capecitabine: a case series. In vivo. 2013;27(4):531-534.

25. Shaib W, Lee V, Saif MW. Bolus 5-fluorouracil as an alternative modality to infusion 5-fluorouracil in a patient with rectal cancer and capecitabine-induced cardiotoxicity. Vivo. 2009;23(5):821-826.

26. Fuchs CS, Moore MR, Harker G, et al. Phase III comparison of two irinotecan dosing regimens in second-line therapy of metastatic colorectal cancer. J Clin Oncol. 2003;21:807-814. doi:10.1200/JCO.2003.08.058

27. Cunningham $D$, Humblet $Y$, Siena $S$, et al. Cetuximab monotherapy and cetuximab plus irinotecan in irinotecan-refractory metastatic colorectal cancer. $N$ Engl J Med. 2004;351:337-345. doi:10.1056/NEJMoa033025

28. Van Cutsem E, Joulain F, Hoff PM, et al. Aflibercept plus FOLFIRI vs. Placebo plus FOLFIRI in second-line metastatic colorectal cancer: a post hoc analysis of survival from the phase III Velour study subsequent to exclusion of patients who had recurrence during or within 6 months of completing adjuvant oxaliplatin-based therapy. Target Oncol. 2016;11(3):383-400.

29. Becouarn Y, Rougier P. Clinical efficacy of oxaliplatin monotherapy: phase II trials in advanced colorectal cancer. Semin Oncol. 1998;25(2 Suppl 5):23-31.

30. Grivicich I, Mans DR, Peters GJ, Schwartsmann G. Irinotecan and oxaliplatin: an overview of the novel chemotherapeutic options for the treatment of advanced colorectal cancer. Braz J Med Biol Res. 2001;34(9):1087-1103. doi:10.1590/S0100-879X2001000900001

31. Haller DG, Rothenberg ML, Wong AO, et al. Oxaliplatin plus irinotecan compared with irinotecan alone as second-line treatment after single-agent fluoropyrimidine therapy for metastatic colorectal carcinoma. J Clin Oncol. 2008;26(28):4544-4550. doi:10.1200/ JCO.2008.17.1249

32. Jonker DJ, O'Callaghan CJ, Karapetis CS, et al. Cetuximab for the treatment of colorectal cancer. $N$ Engl J Med. 2007;357:2040-2048. doi:10.1056/NEJMoa071834

33. Van Cutsem E, Peeters M, Siena S, et al. Open-label phase III trial of panitumumab plus best supportive care compared with best supportive care alone in patients with chemotherapy- refractory metastatic colorectal cancer. J Clin Oncol. 2007;25:1658-1664. doi:10.1200/ JCO.2006.08.1620

34. Grothey A, Van Cutsem E, Sobrero A, et al. Regorafenib monotherapy for previously treated metastatic colorectal cancer (CORRECT): an international, multicenter, randomized, placebo-controlled, Phase 3 trial. Lancet. 2013;381(9863):303-312. doi:10.1016/S01406736(12)61900-X
35. Le DT, Kim TW, Van Cutsem E, et al. Phase II open-label study of pembrolizumab in treatment-refractory, microsatellite instability-high/mismatch repair-deficient metastatic colorectal cancer: KEYNOTE-164. J Clin Oncol. 2020;38(1):11-19. doi:10.1200/ JCO.19.02107

36. Ferrarotto R, Machado K, Mak MP, et al. A multicenter, multinational analysis of mitomycin $\mathrm{C}$ in refractory metastatic colorectal cancer. Eur J Cancer. 2012;48:820-826. doi:10.1016/j.ejca.2012. 01.008

37. Saif MW, Kaley K, Brennan M, Garcon MC, Rodriguez G. Mitomycin-C and capecitabine (MIXE) as salvage treatment in patients with refractory metastatic colorectal cancer: a retrospective study. Anticancer Res. 2013;33(6):2743-2746.

38. Ehrlich MI, Kaley K, Smith M, Saif WM. Safety and efficacy of s-MOX regimen in patients with colorectal cancer who developed cardiotoxicity following fluoropyrimidine administration: a case series. Arch Med Case Rep. 2020;2(1):23-29.

39. Scheithauer W, Kornek GV, Brugger S, et al. Randomized phase II study of irinotecan plus mitomycin $\mathrm{C}$ vs. oxaliplatin plus mitomycin $\mathrm{C}$ in patients with advanced fluoropyrimidine/leucovorin-pretreated colorectal cancer. Cancer Invest. 2002;20(1):60-68. doi:10.1081/ CNV-120000367

40. Comella P, Biglietto M, Casaretti R, et al. Irinotecan and mitomycin $\mathrm{C}$ in 5-fluorouracil-refractory colorectal cancer patients. A phase I/II study of the Southern Italy cooperative oncology group. Oncology. 2001;60(2):127-133. doi:10.1159/000055309

41. Petrelli F, Barni S, Bertocchi P, Zaniboni A. TAS-102, the first "cardio-gentle" fluoropyrimidine in the colorectal cancer landscape? BMC Cancer. 2016;16:386. doi:10.1186/s12885-016-2409-8

42. Stewart T, Pavlakis N, Ward M, et al. Cardiotoxicity with 5-fluorouracil and capecitabine: more than just vasospastic angina. Intern Med J. 2010;40:303-307. doi:10.1111/j.1445-5994.2009.02144.x

43. Saif MW, Smith M, Maloney A. The first case of severe takotsubo cardiomyopathy associated with 5-fluorouracil in a patient with abnormalities of both dihydropyrimidine Dehydrogenase (DPYD) and Thymidylate Synthase (TYMS) genes. Cureus. 2016;8(9):e783.

44. Cianci G, Morelli MF, Cannita K, et al. Prophylactic options in patients with 5-fluorouracil-associated cardiotoxicity. $\mathrm{Br} J$ Cancer. 2003;88(10):1507-1509. doi:10.1038/sj.bjc.6600967

45. Kinhult S, Albertsson M, Eskilsson JCM, et al. Antithrombotic treatment in protection against thrombogenic effects of 5-fluorouracil on vascular endothelium: a scanning microscopy evaluation. Scanning. 2001;23:1-8. doi:10.1002/sca.4950230101

46. Rezkalla S, Kloner RA, Ensley J, et al. Continuous ambulatory ECG monitoring during fluorouracil therapy: a prospective study. J Clin Oncol. 1989;7:509-514. doi:10.1200/JCO.1989.7.4.509

47. Ma WW, Saif MW, El-Rayes BF, et al. Emergency use of uridine triacetate for the prevention and treatment of life-threatening 5-fluorouracil and capecitabine toxicity. Cancer. 2017;123:345. doi:10.1002/cncr.30321
OncoTargets and Therapy

\section{Publish your work in this journal}

OncoTargets and Therapy is an international, peer-reviewed, open access journal focusing on the pathological basis of all cancers, potential targets for therapy and treatment protocols employed to improve the management of cancer patients. The journal also focuses on the impact of management programs and new therapeutic agents and protocols on patient perspectives such as quality of life, adherence and satisfaction. The manuscript management system is completely online and includes a very quick and fair peer-review system, which is all easy to use. Visit http://www.dovepress.com/ testimonials.php to read real quotes from published authors. 